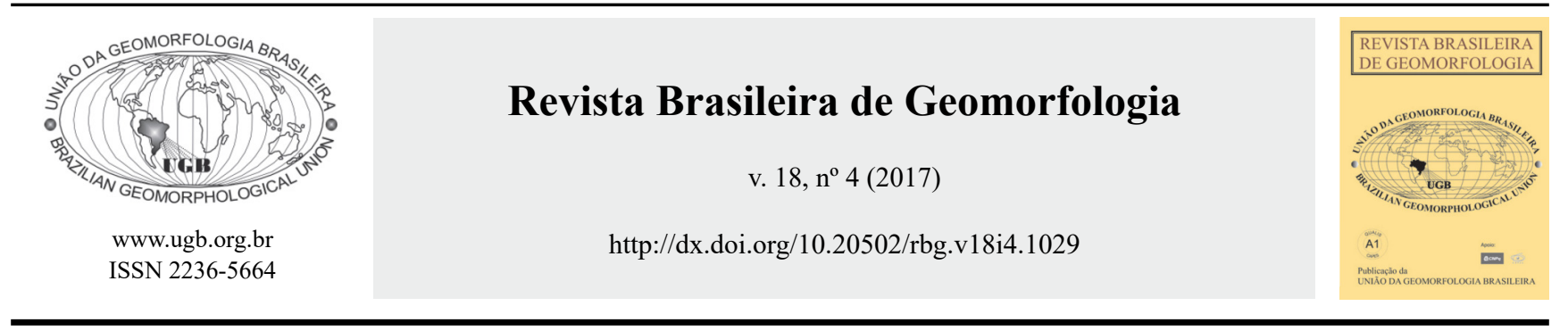

\title{
AVALIAÇÃO DOS PROCESSOS EROSIVOS NO PLANALTO OCIDENTAL PAULISTA: UM ESTUDO DE CASO EM BUSCA DAS INTERAÇÕES ESPACIAIS
}

\section{EVALUATION OF PROCESSES OF EROSION IN THE WESTERN PLATEAU OF SÃO PAULO: A CASE STUDY AIMING THE SPATIAL INTERACTIONS}

\author{
Felipe Augusto Scudeller Zanatta \\ Instituto de Geociências e Ciências Exatas, Universidade Estadual Paulista \\ Avenida 24A n. 1515, Bela Vista, Rio Claro, São Paulo, CEP: 13506-900, Brasil \\ Email: Felipeasz@hotmail.com \\ Cenira Maria Lupinacci \\ Instituto de Geociências e Ciências Exatas, Universidade Estadual Paulista \\ Avenida 24A n. 1515, Bela Vista, Rio Claro, São Paulo, CEP: 13506-900, Brasil
}

Email:Cenira@rc.unesp.br

Marcos Norberto Boin

Universidade Federal da Grande Dourados

Rodovia Dourados-Itanhum, $\mathrm{km}$ 12, Cidade Universitária. CEP: 78804-970, Brasil

Email:Boinmar@hotmail.com

\section{Informações sobre o Artigo}

Recebido (Received):

22/04/2017

Aceito (Accepted):

04/07/2017

\section{Palavras-chave:}

Processos Erosivos; Variáveis Físicas e Antrópicas; Gráficos em Rede.

\section{Keywords:}

Erosive Processes; Physical and Anthropic Variables; Network Graphics.

\section{Resumo:}

A preocupação com a erosão do solo, sobretudo em áreas rurais, vem aumentando em diversos países. Encontra-se a temática em pesquisas divulgadas em periódicos nacionais e internacionais, os quais indicam a influência significativa da ação humana na escala temporal dos fenômenos denudativos. Considerando o tema, o objetivo deste artigo é avaliar essa problemática na bacia do ribeirão Areia Dourada, localizada no município de Marabá Paulista (SP). Por meio do uso de dados advindos de diversos mapeamentos, informações sobre a região foram quantificadas e sistematizadas na forma de gráfico em rede. Assim, buscou-se avaliar a influência dos fatores físicos e da ação humana no desencadeamento e desenvolvimento das formas erosivas, considerando a área de estudo como um exemplo representativo da problemática erosiva no Oeste Paulista. O esquema de gráfico possibilitou aferir um grande volume de informações em um mesmo modelo, de modo a destacar que o uso da terra, sobretudo a pecuária, impacta de forma significativa no desencadeamento dos processos denudativos, indicando o caráter catalisador da ação humana, que generaliza a ação morfodinâmica. Contudo, os dados também demonstram que as formas erosivas só atingem nível de voçorocamento onde as características físicas sugerem maior predisposição a tais processos, como as concavidades das vertentes. Assim, considera-se que o uso do gráfico em rede possibilitou a avaliação das combinações entre as classes temáticas em que o processo erosivo se desenvolve com maior intensidade, bem como a influência da ação humana. Constatou-se que 
os fenômenos erosivos, muitas vezes, ocorrem em setores cujas características físicas não indicam potencialidade ao seu desenvolvimento, como o surgimento de feições erosivas lineares em setores de topo com energia do relevo fraca. Fatos como este se devem à ação do uso da terra, principalmente, no caso estudado, das pastagens.

\begin{abstract}
:
The concern about soil erosion, especially in rural areas, has been increasing in several countries. The thematic is found in researches published in national and international journals, which indicate the significant influence of human action on the temporal scale of denudatory phenomena. Considering it, this article aims to evaluate this problem in the river basin of Areia Dourada, located in the city of Marabá Paulista (SP), through the use of data from various mappings which were systematized in network graphics. We seek to evaluate the influence of physical factors and human action on the triggering and development of erosive forms, considering the area of study as a representative example of erosive problems in São Paulo. As a result, the chart scheme made it possible to gauge a large volume of information in a single model, in order to highlight that land use, especially cattle raising, has a significant impact on the development of denudatory processes, which indicates the catalytic character of the human action that generalizes the morphodynamic action. However, the data also show that the erosive forms only reach gullying level where the physical characteristics suggest a greater predisposition to such processes, as the concavities of the slopes. Therefore, the use of the network graphic allowed to evaluate the combinations between the thematic classes in which the erosive process develops with greater intensity, as well as the influence of the human action. It was found that erosive phenomena often occur in sectors whose physical characteristics do not indicate potential for their development, such as the appearance of linear erosive features in top sectors with low relief energy. Such facts are due to the action of land use, especially, in the case studied, of pastures.
\end{abstract}

\section{Introdução}

A erosão do solo representa um problema de crescente preocupação, discutido em diversos artigos nacionais e internacionais, muitos dos quais apontam a interferência humana como catalisadora dos processos erosivos, uma vez que estes passam a ocorrer em distintos ambientes físicos ao longo do planeta (Cunha et al., 1999; Stein, Ponçano e Saad, 2003; Marker et al., 2007; Cebecauer e Hofierka, 2008; Lesschen et al., 2008; Fu et al., 2009; Perez-Filho e Quaresma, 2013; Garcia-Ruiz et al, 2013; Bastos, Maniesi e Gomes, 2015).

García-Ruiz et al. (2013), em revisão bibliográfica sobre a região mediterrânea, constataram que a erosão do solo se tornou um dos mais significativos problemas ambientais, sendo o foco de diversas pesquisas na Espanha, Itália, França, Portugal, Israel, Grécia e norte da África. Tais pesquisas buscam avaliar como as atividades humanas impactaram nos ambientes, tornando a agricultura insustentáveis a curto e médio prazo. Na porção sul da região de Toscana, Itália, Marker et al. (2007) identificaram que as mudanças no uso da terra desempenharam papel importante na erosão do solo, sobretudo devido à sua intensificação por meio da mecanização da agricultura, aplicação de fertilizantes, pesticidas e manejos das encostas. Na região semiárida no sudeste da Espanha, de acordo com Lesschen et al. (2008), terraços agrícolas mal projetados em áreas de cultivos de oliveiras e vinhedos resultaram na ativação de processos erosivos que removeram, em média, 87 toneladas/ha/ano de solo e tornaram tais campos improdutivos, ao ponto de serem abandonados pelos produtores. Em clima semelhante, no Loess Plateau na China, Fu et al. (2009), ao analisarem diversas variáveis ambientais em setores atingidos por processos erosivos, consideraram o uso inadequado como fator chave na degradação dos solos, mais importante que o clima e a topografia. Cabecauer e Hofierka (2008) identificaram que mudanças na paisagem de 1990 a 2000, sobretudo com a conversão de florestas em terras aráveis, aumentaram consideravelmente o risco e a frequência de processos erosivos em regiões montanhosas e de alta declividade na Eslováquia.

No Brasil, diversos artigos também destacam a influência da ação humana nos processos denudativos. No sudoeste da Amazônia, em solos predominantemente arenosos, Bastos, Maniesi e Gomes (2015) constaram que a expansão da bovinocultura na região tem promovido alterações dos índices de vulnerabilidade natural à erosão, uma vez que a área não é adequada para a atividade pecuária. Cunha et al. (1999), em análise das bacias do Córrego Jacu e Santo Antônio, Rio Claro (SP), identificaram que o uso da terra tem a capacidade de criar feições erosivas em situações em que os parâmetros naturais 
apresentam baixo potencial ao desenvolvimento destas. Perez-Filho e Quaresma (2011), ao analisarem diversos trabalhos que abordaram a problemática erosiva no oeste, noroeste e leste do estado de São Paulo e o processo de desertificação no Brasil central, constataram que tais fenômenos não podem ser explicados unicamente pelos elementos naturais, uma vez que esses processos, de ocorrência característica de escala temporal geológica, passaram a se desenvolver na escala de tempo histórico, caracterizando-se, portanto, como processos geomorfológicos de gênese antrópica. Stein, Ponçano e Saad (2003) constataram em estudo sobre a bacia do Rio Santo Anastácio, que as alterações profundas, introduzidas pelas diversas atividades antrópicas, modificaram o regime de escoamento das águas pluviais, intensificando a atividade erosiva que afeta diretamente os cursos fluviais da bacia.

A região do Oeste Paulista, embora com histórico de ocupação mais recente que as demais regiões do estado - datando o final do séc. XIX e início do séc. XX (MONBEIG, 1984; FERRARI-LEITE, 1999)-, desponta em termos de quantidade de formas erosivas, o que muito se deve à devastação promovida no processo de ocupação, em solos predominantemente arenosos (IPT, 2015). $\mathrm{Na}$ Unidade de Gerenciamento de Recursos Hídricos do Pontal do Paranapanema (UGRHI-22), que abrange 26 municípios ( $4 \%$ do total do estado), localizados na área limítrofe com os estados do Mato Grosso e Paraná, foram registradas 3.261 formas erosivas em ravinas e voçorocas, $12,1 \%$ de todo estado, sendo que apenas no município de Marabá Paulista encontram-se 371 dessas formas erosivas (IPT, 2012).

Assim, considerando a relevância da temática e a problemática erosiva expressiva no Oeste Paulista, para o estudo de caso foi selecionada a alta bacia do ribeirão Areia Dourada, localizada inteiramente no município de Marabá Paulista (SP). Na bacia estudada, em seus 46 $\mathrm{km}^{2}$ de área, encontram-se 530 formas erosivas lineares, sendo 385 sulcos, 138 ravinas e sete voçorocas, além de 137 setores em que se registraram marcas que indicam erosão laminar (ZANATTA, 2014).

Segundo Christofoletti (1980), os fenômenos naturais, dentre os quais se encontra os erosivos, podem ser compreendidos por meio de sua conceituação como sistema. Nesta abordagem, identifica-se a estrutura do sistema, os elementos, seus atributos e principalmente suas relações de maneira dinâmica, as quais são reguladas por fatores externos, como a ação do ritmo climático, com inputs de matéria e energia. A maneira como a estrutura do sistema absorve e dissipa esses inputs de- pende da estrutura. Cada estrutura, em sua especificidade de elementos e atributos, permite determinado limiar de funcionamento, com capacidade de processar certa quantidade de matéria e energia. Quando superado esse limiar, ocorrem alterações na dissipação da energia, de modo a gerar modificações nas formas, como consequência dos processos que ali passaram a se desenvolver. Sob esta perspectiva, a ação antrópica também se insere como agente geomorfológico, uma vez que, ao modificar direta e/ou indiretamente a estrutura do sistema e também promover inputs de matéria e energia, altera a localização e temporalidade de determinados fenômenos. Desse modo, as formas erosivas indicam que o sistema teve sua estrutura alterada e/ou seu limiar de funcionamento excedido, o que se expressa pela localização e desenvolvimento dos fenômenos erosivos.

Nesse contexto, o objetivo do artigo consiste na avaliação da influência das variáveis físicas (geologia, solos e energia do relevo) e antrópicas (uso e cobertura superficial da terra e técnicas conservacionistas) na localização das formas erosivas e desenvolvimento dos processos erosivos. Para tanto, apresenta-se um instrumento em forma de gráfico de rede, concebido a partir de noções básicas da abordagem sistêmica:

\section{Caracterização da Área}

A alta bacia do ribeirão Areia Dourada localiza-se na bacia sedimentar do Paraná, no Planalto Ocidental Paulista (Figura 1).

O substrato rochoso é composto de Formações areníticas caractereizadas como Santo Anastácio e Adamantina, ambas pertencentes ao Grupo Bauru (FERNANDES, 1998), datadas do Mesozoico. A primeira deriva de um ambiente fluvial anastomosado e meandrante, apresentando deficiência de material pelítico, sendo predominantemente quartzosa. Sobreposta a esta, encontra-se a Formação Adamantina, que ocorre em bancos espessos ou acamamento plano-paralelo. Os diferentes ambientes de sedimentação da Formação Adamantina, fluvial e lacustre, proporcionaram a formação de camadas menos permeáveis (pelitos) - sobretudo pela cimentação por carbonato de cálcio- intercaladas por camadas mais permeáveis, o que atribui estruturas hidrodinâmicas internas ao extrato; na área estudada, a Formação Santo Anastácio encontra-se restrita à baixa vertente e aos fundos de vale, enquanto a Formação Adamantina, distribui-se da média vertente ao topo (IPT, 1994; STEIN, 1999). 


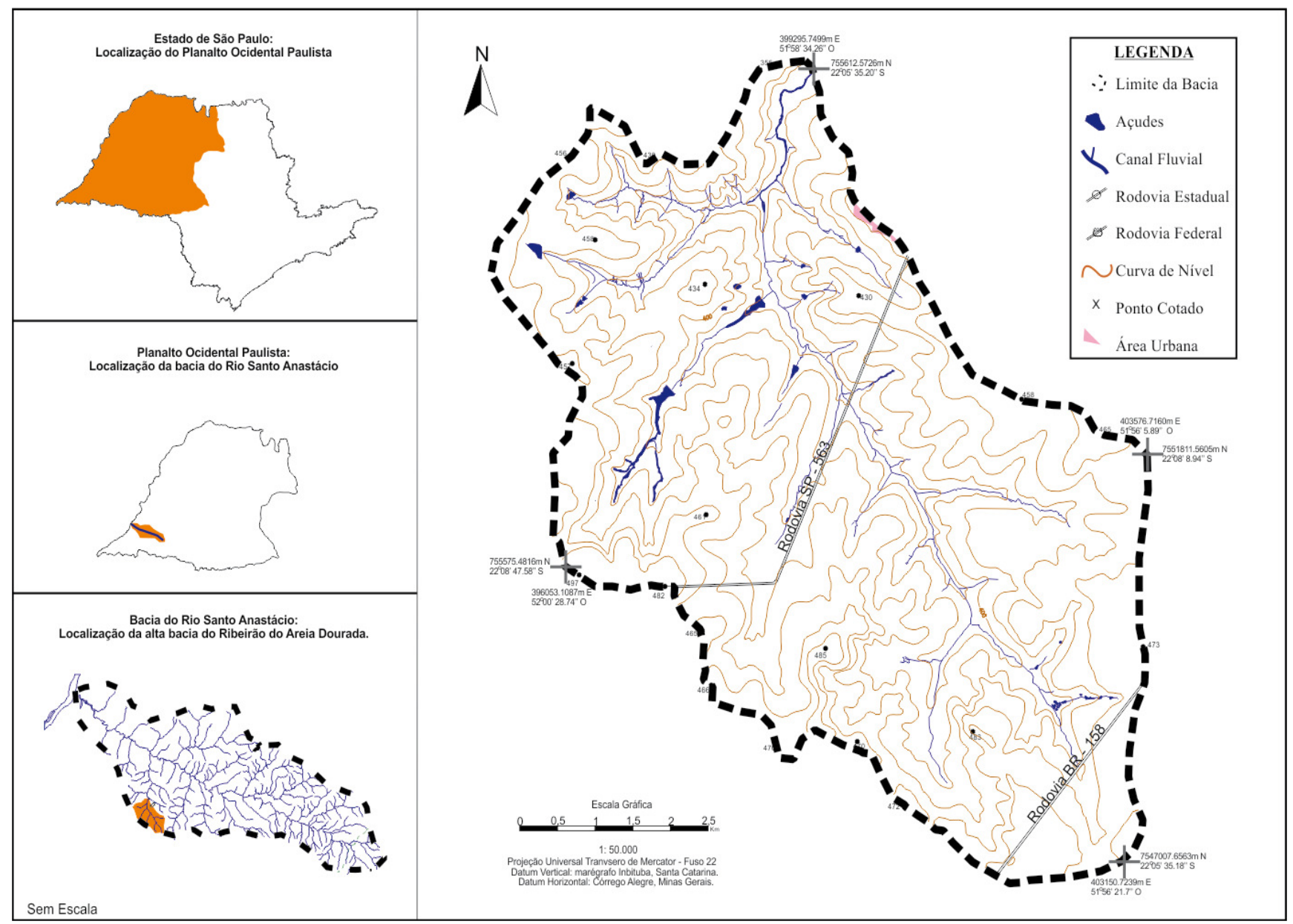

Figura 1 - Localização da alta bacia do ribeirão Areia Dourada, Marabá Paulista (SP)

Pela diferença de resistência da Formação Adamantina, sobretudo na transição do topo para alta vertente, ocorrem rupturas topográficas abruptas que condicionam o aumento do declive dos terrenos a jusante. Por vezes, surgem extensas áreas com afloramento d'água - derivados da intercalação de bancos silto-argilosos e arenosos-, de maneira a gerar nascentes de canais perenes e filetes de água intermitentes. Estes afloramentos ocorrem por todo setor oeste e nordeste da bacia.

A posição das falhas geológicas, nas quais o ribeirão Areia Dourada se encontra, sugere a influência destas no formato assimétrico da bacia, com implicações no relevo da área, onde à oeste as vertentes são mais extensas e os topos amplos e à leste, predominam topos estreitos e vertentes mais dissecadas.

As rupturas topográficas com afloramento d'água e a dissimetria da bacia se refletem no desenvolvimento da rede de drenagem. Em análise da hierarquia fluvial, com base em Shreve (1967), averígua-se que à leste, entre as vertentes estreitas, os canais são pouco desenvolvidos, predominantemente de primeira ordem, atingindo terceira ordem apenas próximo à ruptura topográfica com afloramento do lençol, à nordeste. Já a porção oeste da bacia, em meio às vertentes mais extensas, desenvolvem-se canais das mais variadas ordens: em terrenos onde não ocorrem rupturas com afloramento de água, os tributários do ribeirão Areia Dourada são de primeira à terceira ordem; no caso de a jusante das rupturas com afloramento de água, os tributários são de quinta até vigésima sétima ordem.

Nos fundos de vale e a jusante das rupturas topográficas, o declive é acentuado, entre $15 \%$ e $30 \%$, e condiciona a esses terrenos o potencial de acumular energia de muito forte a forte, salvo situações em que ocorrem vertentes convexizadas nos interflúvios, que 
levam a energia do relevo desses setores à intensidade média. Predomina nas demais vertentes e nos topos secundários, energia medianamente forte. Nos topos, sobretudo na porção sudoeste e oeste da bacia, próximo à cabeceira, a energia é fraca, enquanto nas demais áreas de topo a energia, de modo predominante, é média.

A região do Oeste Paulista está submetida a um clima tropical úmido, com estações bem definidas: primavera e verão quentes e chuvosos; outono e inverno frios e secos. Quanto à erosividade da chuva, Boin (2000) atenta para a atuação dos sistemas atmosféricos na primavera e verão, quando há maior erosividade por conta das chuvas, que ocorrem com maior frequência, de forma prolongada ou com alta intensidade.

Sob essas condições, desenvolvem-se solos predominantemente arenosos, sobretudo de areia fina, de baixa agregação das frações granulométricas (CARVALHO, 1997). Nas vertentes e topos da alta bacia do ribeirão Areia Dourada, a autora identificou três tipos de solos: Latossolo Vermelho Distrófico, com A moderado de textura argilosa; Argissolo Vermelho Abrupto Distrófico Epieutrófico Tb, com A moderado, de textura arenosa; e Neossolo Litólico Eutrófico, com A Chernozêmico, de textura arenosa.

A localização dos tipos de solo na alta bacia do ribeirão Areia Dourada sugere que a forma do relevo e a resistência das litofácies da Formação Adamantina são fatores relevantes no desenvolvimento e na distribuição dos solos pela bacia. Presente nos topos amplos e nas vertentes pouco dissecadas à oeste, o Latossolo apresenta horizonte $\mathrm{A}$, que varia de $20 \mathrm{~cm}$ a $40 \mathrm{~cm}$, estrutura que varia de pequena a média granular, com $1,43 \%$ de carbono orgânico e $46 \%$ de poros; e horizonte $\mathrm{B}$, com espessura com mais de $150 \mathrm{~cm}$, estrutura fraca, maciça porosa, que se desfaz em granular ou pequenos blocos, sendo que os poros correspondem a $44 \%$ do volume deste horizonte (CARVALHO, 1997). O Argissolo apresenta horizonte A de $80 \mathrm{~cm}$ de espessura, dividindo-se nos horizontes Ap, onde a estrutura apresenta fraca média granular e grãos simples, e AB, no qual a estrutura é fraca em blocos subangulares. A quantidade de carbono orgânico é bem reduzida, $0,52 \%$, enquanto os poros correspondem a $47 \%$ do volume total. Já o horizonte $\mathrm{Bt}$, com espessura de $150 \mathrm{~cm}$ e estrutura fraca em blocos subangulares, a quantidade de carbono orgânico se reduz para $0,25 \% \mathrm{e}$ os poros para $44 \%$. Essa classe de solo é predominante nas vertentes da bacia, sobretudo nas mais dissecadas, e em áreas de topos estreitos (CARVALHO, 1997). Restritos ao topo à sudoeste e topo secundário à noroeste, sobre litofácies mais resistentes da Formação Adamantina, o Neossolo apresenta horizonte Ap com espessura de $40 \mathrm{~cm}$, estrutura fraca, pequena e média granular e grãos simples, com $87 \%$ da fração areia, $8 \%$ de silte e $5 \%$ de argila. A transição é abrupta, quebrada e descontínua para o horizonte $\mathrm{A} / \mathrm{R}, 40 \mathrm{~cm}$, de textura arenosa e estrutura fraca, pequena, granular, e composto por $81 \%$ de fração areia, $9 \%$ silte e $10 \%$ argila (CARVALHO, 1997). As características dos solos da bacia indicam alguns aspectos da erodibilidade a serem considerados: baixa coesão promovida pela alta porcentagem de areia fina, reduzida estabilidade pela baixa porcentagem de carbono orgânico e argila, e estrutura fraca.

Quanto ao uso da terra, predominam as pastagens, que ocupam $54,72 \%$ de toda a bacia, seguido da cana-de-açúcar com $31,25 \%$ e pasto sujo com $12,85 \%$. Atenta-se à presença reduzida de vegetação nativa, em pequenos fragmentos dispersos por toda área, que, somados, ocupam $0,69 \%$, enquanto reflorestamentos correspondem a $0,3 \%$. A modificação brusca da cobertura superficial nativa promoveu o desencadeamento de distintos processos denudativos, nos quais se identificaram 530 formas erosivas lineares, sendo 385 sulcos, 138 ravinas e sete voçorocas, além de 137 marcas que indicam erosão laminar. A ação morfogenética acelerada nos topos e vertentes desencadeou o solapamento das margens em alguns trechos dos canais fluviais e assoreamento nos demais, alterando significativamente os fundos de vale.

\section{Materiais, Técnicas e Método}

Os dados de topografia da área foram obtidos através das cartas do Instituto Brasileiro de Geografia e Estatística (IBGE) de 1976, em escala 1:50.000, nas folhas de Marabá Paulista (SF-22-Y-B-II-1) e Ribeirão das Anhumas (SF-22-Y-B-I-2). Destas, foram vetorizadas as curvas de nível, com equidistância de $20 \mathrm{~m}$, e adicionados os respectivos valores altimétricos e os pontos cotados. 
A carta geológica teve como base o trabalho de Stein (1999), quem, a partir dos dados de geologia em escala 1: 250.000 elaborado pelo Instituto de Pesquisas Tecnológicas do estado de São Paulo (IPT), em 1994, reambulou para escala 1: 100.000, ajustando os limites das formações em toda a bacia do Rio Santo Anastácio. Neste artigo, com algumas averiguações em campo, sobretudo pelas rupturas de declive, reajustaram-se os limites das Formações, compatibilizando a escala dos dados para 1:50.000.

As classes de solos foram obtidas no trabalho coordenado por Carvalho (1997), que utilizou fotografias do aerolevantamento de Presidente Venceslau de 1997, escala de voo 1:35.000, e coleta de amostras em campo. A referida autora elaborou a carta de solos da bacia do rio Santo Anastácio na escala de semidetalhe, 1: 100.000.

Quanto ao relevo, a morfometria foi extraída de Boin; Zanatta e Lupinacci (2014), os quais utilizaram a proposta de Mendes (1993) para determinar a energia do relevo. Os autores tiveram como base as cartas topográficas do IBGE (1976), em escala 1: 50.000. Para definir as classes de energia do relevo, avaliaram qualitativamente a combinação de dados de declividade, de dissecação horizontal e de dissecação vertical dos terrenos. As classes de energia de forte a muito forte abarcam terrenos com declives de $15 \%$ a $\geq 20 \%$, dissecação horizontal $<100 \mathrm{~m}$ a $200 \mathrm{~m}$, ou com dissecação vertical $>100 \mathrm{~m}$. A classe de energia medianamente forte a média compreende os terrenos com declive de $10 \%$ a $15 \%$, com dissecação horizontal de $200 \mathrm{~m}$ a $400 \mathrm{~m}$, ou vertical de $800 \mathrm{~m}$ a $100 \mathrm{~m}$, como também a combinação entre declives de $5 \%$ a $10 \%$ e dissecação horizontal de $400 \mathrm{~m}$ a $800 \mathrm{~m}$, ou declives de $2 \%$ a $5 \%$ e dissecação horizontal de $800 \mathrm{~m}$ a $1600 \mathrm{~m}$ e dissecação vertical de $40 \mathrm{~m}$ a $60 \mathrm{~m}$. A energia fraca incide nos demais setores com declives de $2 \%$ a $5 \%$, com dissecação horizontal de $800 \mathrm{~m}$ a $1600 \mathrm{~m}$ ou dissecação vertical de $40 \mathrm{~m}$ a $60 \mathrm{~m}$. Estes dados foram complementados com outros, referentes à compartimentação morfológica da área, delimitando os setores de topo e as formas de vertentes côncavas e convexas, por meio da interpretação dos contornos das curvas de nível.

A carta de uso e cobertura superficial da terra, as técnicas conservacionistas e as formas erosivas foram identificadas a partir da fotointerpretação do aerolevantamento realizado pela Empresa Paulista de Planejamento Metropolitano (EMPLASA), com 45 centímetros de resolução Ground Sample Distance (GSD), e reambulação em campo nos anos de 2011, 2012 e 2013. Estas informações foram cartografadas e trabalhadas na escala 1: 50.000.

Com a distribuição espacial de todos os dados, estes foram sobrepostos no programa SPRING 5.1.8, organizando as informações no programa Microsoft Excel®. Posteriormente, para criar os gráficos em rede, foi montado um esquema de escala gráfica no programa Corel Draw, no qual os dados foram inseridos manualmente. O tamanho dos círculos que representam as formas erosivas e a espessura das linhas que conectam as classes temáticas aumenta de acordo com a quantidade de informação inserida (Figura 2).

Cabe destacar que na montagem da Tabela 1 não foram contabilizados o total das formas erosivas identificadas em toda área estudada, que somam 530, o que ficou registrado foi a presença de cada tipo de forma erosiva por combinação das variáveis, contabilizando 173 conexões que apresentam alguma forma erosiva. Assim, se em uma combinação foram registrados cinco sulcos, no cruzamento dos dados foi contabilizado apenas a presença dessa feição, pois, o que importa destacar é se as combinações, em suas distintas variações, apresentam ou não determinada forma erosiva e se esta tende ou não ao desenvolvimento para estágios mais avançados do processo erosivo - esta tendência é avaliada indiretamente a partir da presença de formas erosivas em estágios mais avançados.

Para melhor representar o cruzamento dos referidos dados, foram elaborados três gráficos, tendo como critério a suscetibilidade das formas de relevo a distintos processos geomorfológicos: nos topos, prevalece a infiltração; nas vertentes convexas, a tendência de fluxo difuso; nas vertentes côncavas, o escoamento tende a ser concentrado.

Feita a primeira divisão dos gráficos, para cada compartimento do relevo foram conectadas as demais variáveis. Na parte superior do gráfico estão as características físicas referentes à geologia, solos e energia do relevo; na parte inferior, o uso da terra e as práticas conservacionistas. Os dados foram interligados por linhas cuja espessura indica o número de combinações, enquanto as formas erosivas foram discriminadas, em cada variável analisada, através de circunferências de cores distintas, que aumentam conforme a quantidade identificada. 


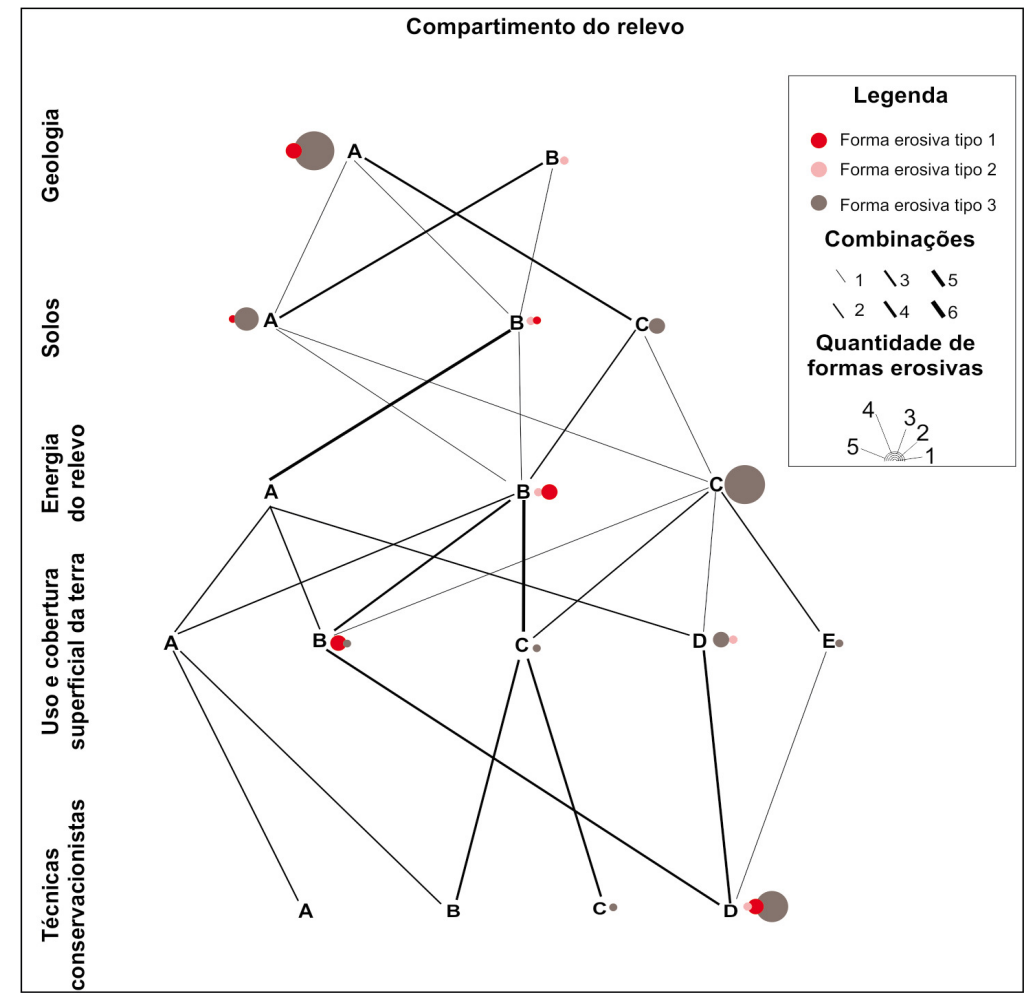

Figura 2 - Modelo de representação do gráfico em rede. As letras em maiúsculo simulam as variáveis de cada classe temática (geologia, solos, energia do relevo, uso e cobertura superficial da terra e técnicas conservacionistas); o tamanho dos circulos indica a quantidade de formas erosivas; e a espessura dos traços, o número de combinações que caracterizam tais formas

Tabela 1: Fragmento da tabela das áreas de topo utilizada para o desenvolvimento dos gráficos em rede

\begin{tabular}{|c|c|c|c|c|c|c|}
\hline $\begin{array}{l}\text { Compartimento } \\
\text { de relevo }\end{array}$ & Geologia & Solo & $\begin{array}{l}\text { Energia do } \\
\text { relevo }\end{array}$ & $\begin{array}{c}\text { Uso e } \\
\text { cobertura } \\
\text { superficial } \\
\text { da terra } \\
\end{array}$ & $\begin{array}{l}\text { Práticas preservacionistas e } \\
\text { conservacionistas }\end{array}$ & Forma erosiva \\
\hline \multirow{15}{*}{ Topo } & \multirow{5}{*}{ Adamantina } & \multirow{5}{*}{ Latossolo } & \multirow{5}{*}{$\begin{array}{l}\text { de média a } \\
\text { medianamente } \\
\text { forte }\end{array}$} & $\begin{array}{l}\text { Cana-de- } \\
\text { açúcar }\end{array}$ & Terraços com mais de 30 metros & Sulco e feições que indicam erosão laminar \\
\hline & & & & Estrada rural & Não identificado & Sulco e feições que indicam erosão laminar \\
\hline & & & & \multirow[b]{2}{*}{ Pasto } & Terraços com mais de 30 metros & Sulco e feições que indicam erosão laminar \\
\hline & & & & & Não identificado & $\begin{array}{l}\text { Sulco, ravina e feições que indicam erosão } \\
\text { laminar }\end{array}$ \\
\hline & & & & Pasto sujo & $\begin{array}{l}\text { Áreas cercada; obliteração; e bacias de } \\
\text { contenção. }\end{array}$ & Sulco e feições que indicam erosão laminar \\
\hline & \multirow{2}{*}{$\begin{array}{l}\text { Santo } \\
\text { Anastácio }\end{array}$} & \multirow{2}{*}{ Latossolo } & \multirow{2}{*}{$\begin{array}{l}\text { de média a } \\
\text { medianamente } \\
\text { forte }\end{array}$} & $\begin{array}{l}\text { Cana-de- } \\
\text { açúcar }\end{array}$ & Terraços com mais de 30 metros & Feições que indicam erosão laminar \\
\hline & & & & Pasto sujo & $\begin{array}{l}\text { Áreas cercada; obliteração; e bacias } \\
\text { de contenção. }\end{array}$ & $\begin{array}{l}\text { Sulco, ravina e feições que indicam } \\
\text { erosão laminar }\end{array}$ \\
\hline & \multirow{8}{*}{ Adamantina } & \multirow{8}{*}{ Argissolo } & \multirow{8}{*}{$\begin{array}{l}\text { de média a } \\
\text { medianamente } \\
\text { forte }\end{array}$} & \multirow{2}{*}{$\begin{array}{l}\text { Cana-de- } \\
\text { açúcar }\end{array}$} & Terraços de 10 a 20 metros & Não identificado \\
\hline & & & & & Terraços de 20 a 30 metros e obliteração & Sulco e feições que indicam erosão laminar \\
\hline & & & & Estrada rural & Não identificado & Sulco \\
\hline & & & & \multirow{4}{*}{ Pasto } & Terraços de 10 a 20 metros & Não identificado \\
\hline & & & & & Terraços de 20 a 30 & $\begin{array}{l}\text { Sulco e feições que indicam erosão } \\
\text { laminar }\end{array}$ \\
\hline & & & & & $\begin{array}{l}\text { Terraços com mais de } 30 \text { metros; } \\
\text { obliteração; e bacias de contenção. }\end{array}$ & $\begin{array}{l}\text { Sulco e feições que indicam erosão } \\
\text { laminar }\end{array}$ \\
\hline & & & & & Bacias de contenção & $\begin{array}{l}\text { Sulco, ravina e feições que indicam } \\
\text { erosão laminar }\end{array}$ \\
\hline & & & & Pasto sujo & Área cercada & Ravina \\
\hline
\end{tabular}




\section{Resultados}

Os gráficos elaborados são apresentados de acordo com o grau de suscetibilidade dos terrenos à ação erosiva. Assim, discute-se inicialmente os topos, considerados como de menor suscetibilidade, a seguir as vertentes convexas e, por fim, as côncavas, avaliadas como as de maior tendência a ação erosiva.
As áreas de topo apresentam um total de 34 combinações entre elementos físicos e antrópicos. As 25 formas erosivas se distribuem de modo mais equilibrado entre os elementos físicos, à exceção da Formação Adamantina, o que se deve, em parte, ao fato desta predominar nas áreas mais elevadas da bacia (Figuras 3 e 4 ).

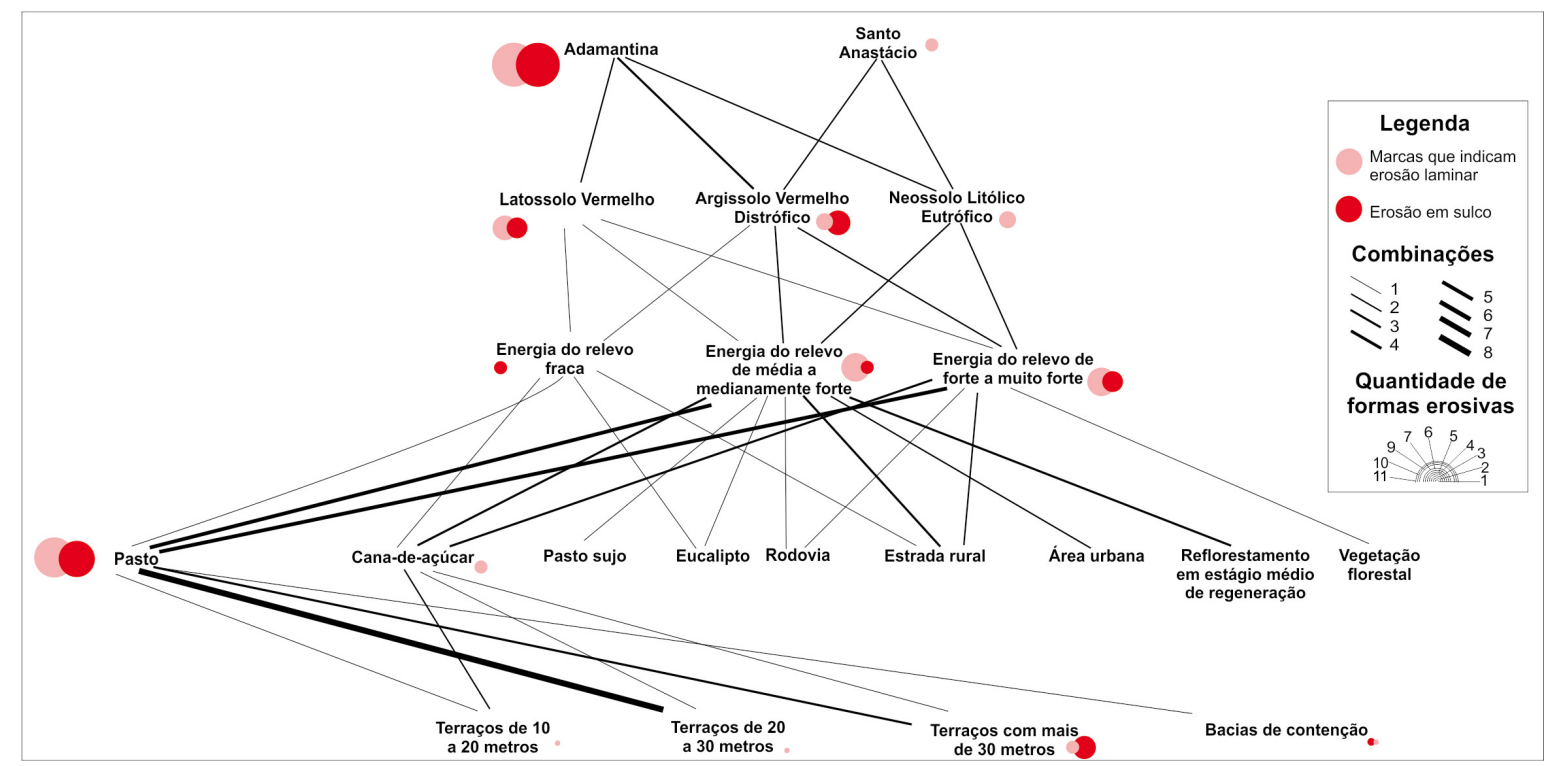

Figura 3 - Interações espaciais em áreas de topo, na alta bacia do ribeirão Areia Dourada, Marabá Paulista (SP)

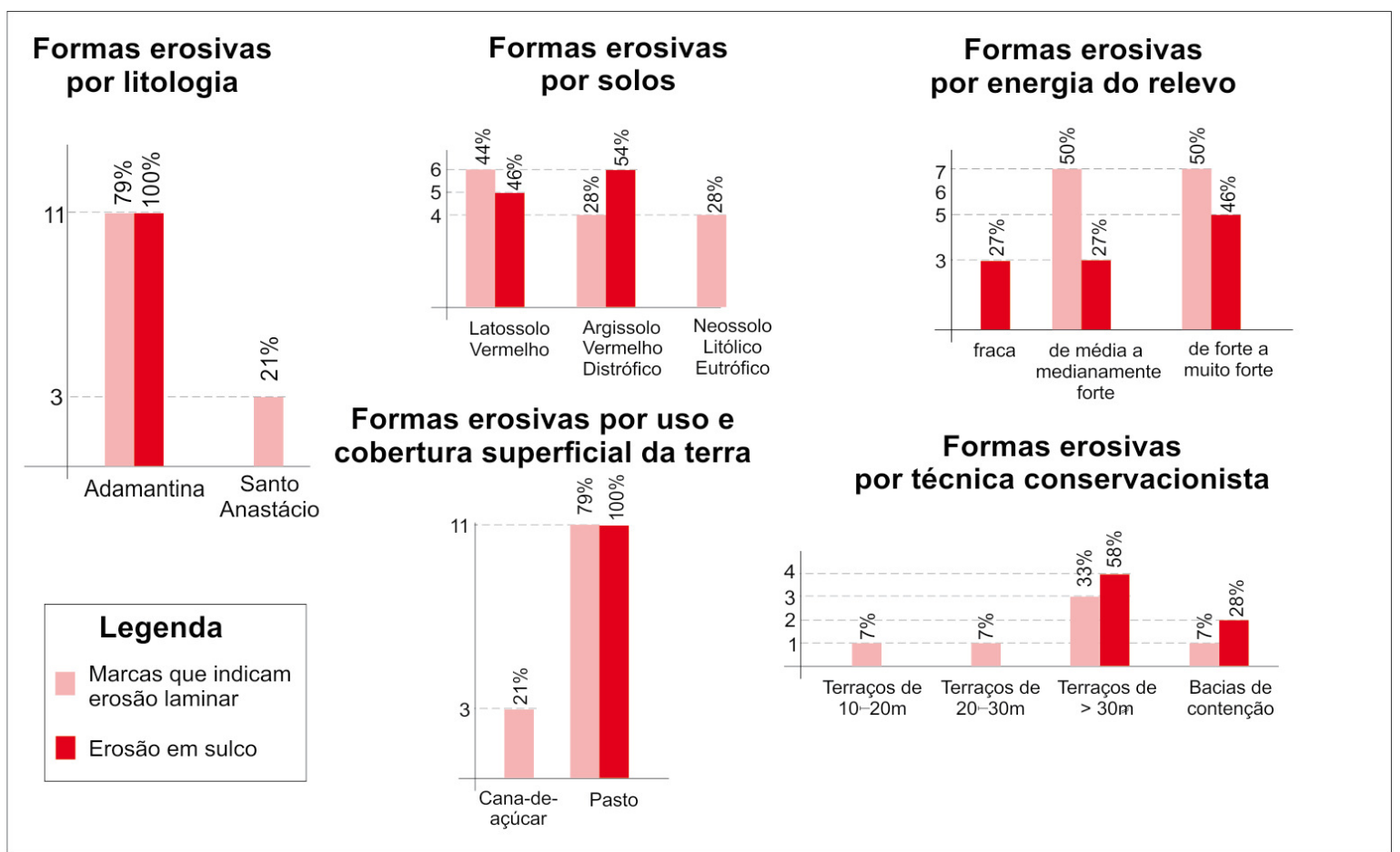

Figura 4 - Formas erosivas organizadas por característica física, uso da terra e técnicas conservacionistas em áreas de topo, na alta bacia do ribeirão Areia Dourada, Marabá Paulista (SP) 
Quanto aos solos, as marcas que indicam erosão laminar ocorrem em todas as classes. Os sulcos se distribuem entre o Latossolo e Argissolo, com maior concentração neste último, enquanto as marcas que indicam erosão laminar apresentam maior incidência no Latossolo (Figura 4). Esse dado indica que nas áreas de topo, o Argissolo tem maior predisposição para o processo linear, em sulco.

$\mathrm{Na}$ energia do relevo, as marcas que indicam erosão laminar se distribuem de maneira idêntica entre as classes de energia média a medianamente forte, e de forte a muito forte (Figura 4). Sobre os sulcos, ocorrem em todas as classes, com maior concentração nas de energia forte a muito forte, o que registra a maior predisposição desses terrenos ao desencadeamento de processos denudativos. Todas as feições denudativas, sobretudo as lineares, principalmente em terrenos de energia fraca, só podem ser compreendidas por meio de algum elemento que perverte a função desses setores. Assim, quando se avalia o uso da terra, identifica-se a concentração dos fenômenos nas áreas de pasto, sobretudo os sulcos erosivos.

A Figura 3 demonstra que as áreas de pasto abarcam praticamente todas as combinações de elementos físicos, de modo a promover a erosão em terrenos pouco suscetíveis, como aqueles de energia fraca em Latossolo Vermelho. Tal situação demonstra que o pastoreio excessivo desses terrenos acaba por perverter a função de infiltração de água, uma vez que o pisoteio compacta a camada superficial do solo, contribuindo para o escoamento superficial e formação tanto de marcas que indicam erosão laminar, como de processos lineares em sulcos. No entanto, os condicionantes físicos atenuam a evolução de tais processos, uma vez que não se registrou na área de topo formas mais desenvolvidas do fenômeno erosivo linear.

Entre as técnicas conservacionistas, constatam-se processos erosivos em todas elas, sendo os terraços com mais de $30 \mathrm{~m}$ de espaçamento e as bacias de contenção (Figura 4) menos eficientes na diminuição do fenômeno erosivo - sobre as bacias ocorrem tanto processos laminares como lineares em sulcos. Os sulcos incidem sobre tais técnicas conservacionistas somente nas áreas de pasto, enquanto as marcas de erosão laminar ocorrem também nas áreas com cana-de-açúcar.

O desenvolvimento de sulcos em terrenos com terraços agrícolas com mais de 30m de espaçamento (Figura 5) e nas bacias de contenção, assim como a ação da erosão laminar em todas as técnicas levantadas, indicam a baixa eficiência de tais técnicas em relação às características das distintas combinações. Das 25 combinações em áreas de topo com alguma forma erosiva identificada, em apenas doze (48\%) foram averiguadas técnicas conservacionista, ou seja, boa parte dos topos em uso encontra-se sem qualquer prática conservacionista associada.

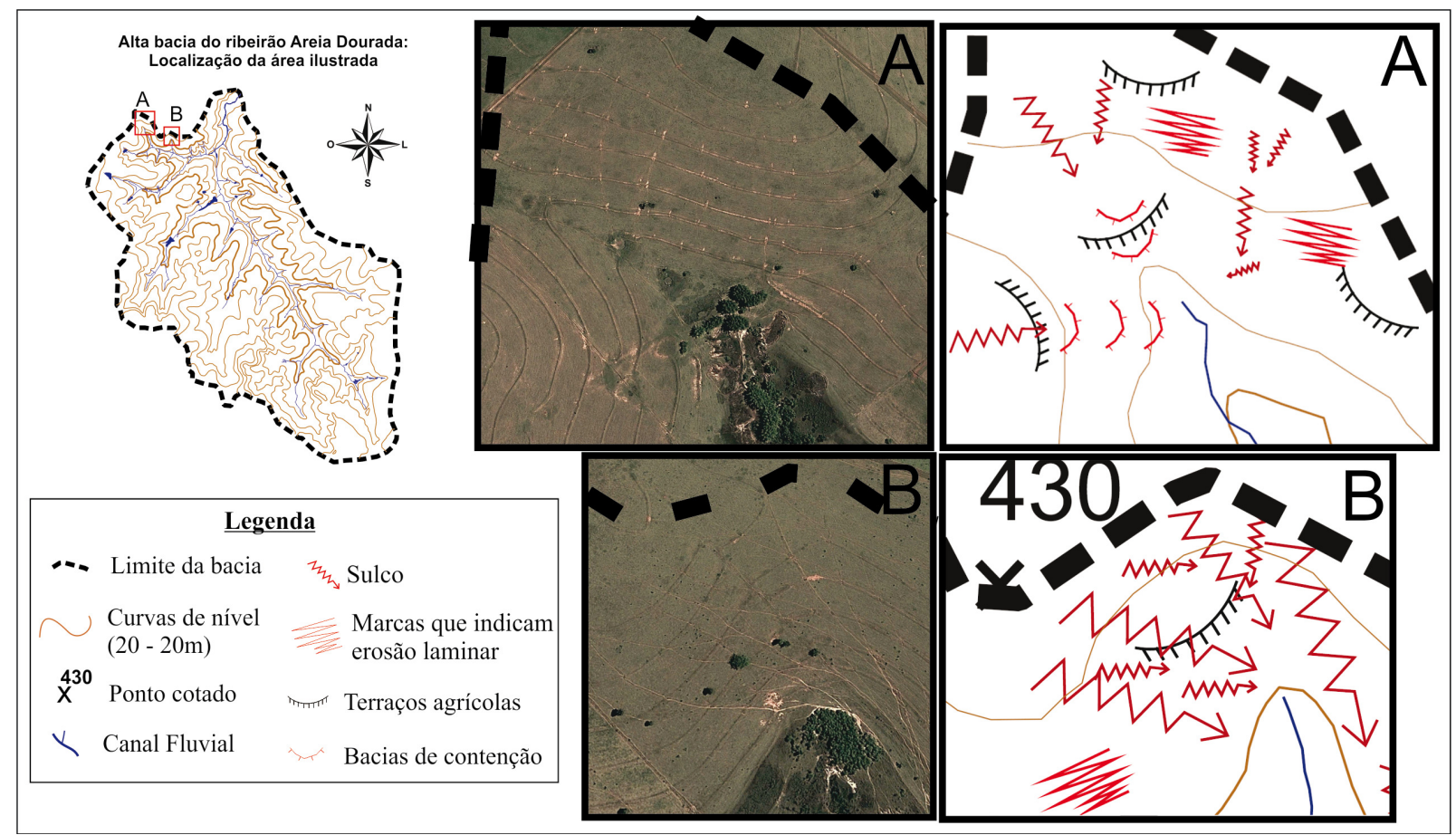

Figura 5 - Identificação e mapeamento de feições erosivas lineares em sulco, em área de topo 
Nas vertentes convexas ocorrem 76 combinações entre elementos físicos e antrópicos. As formas erosivas distribuem-se de forma mais generalizada entre as variáveis do meio físico, quando comparada ao uso da terra; nesse compartimento do relevo, o processo erosivo atinge nível de ravinamento (figuras 6 e 7).

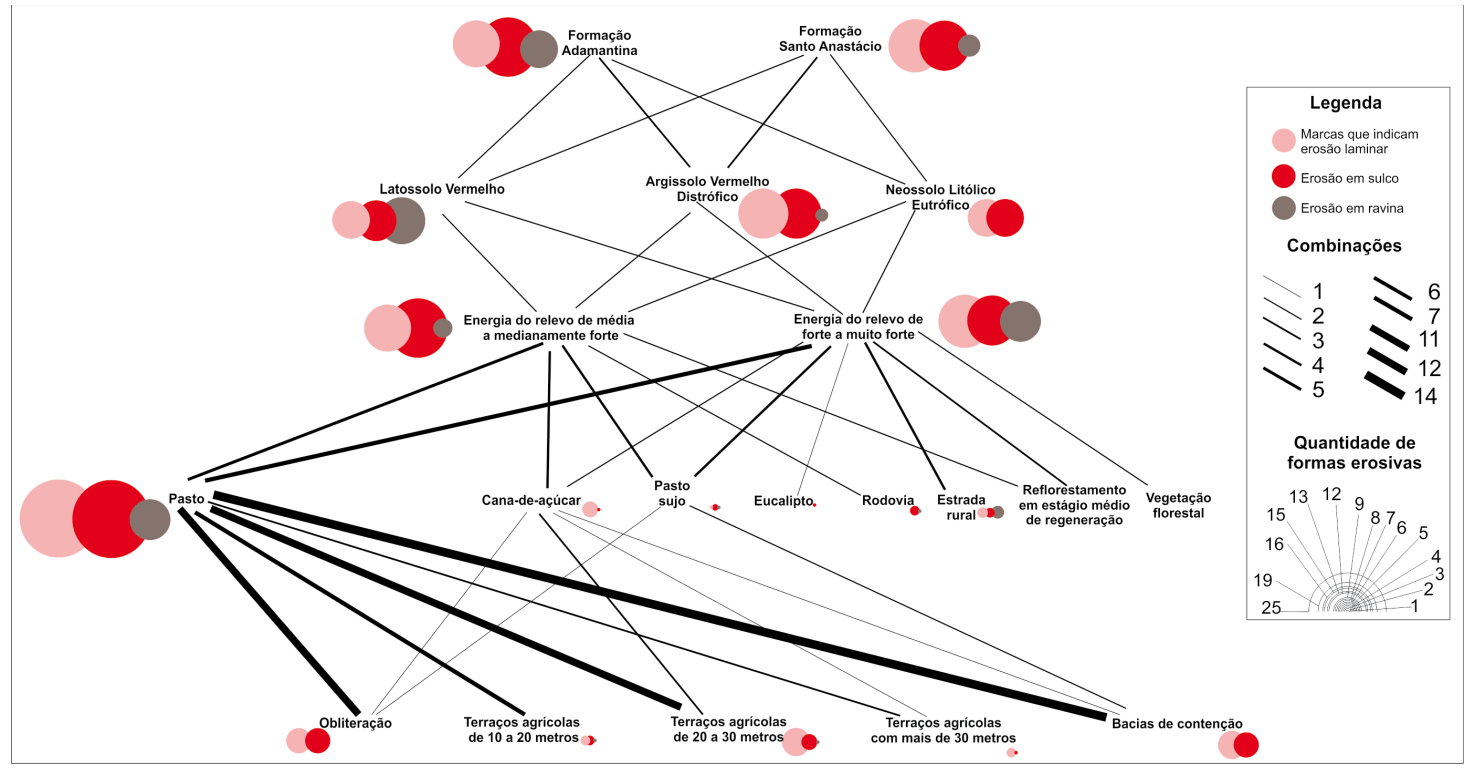

Figura 6 - Interações espaciais em vertentes convexas na alta bacia do ribeirão Areia Dourada, Marabá Paulista (SP)

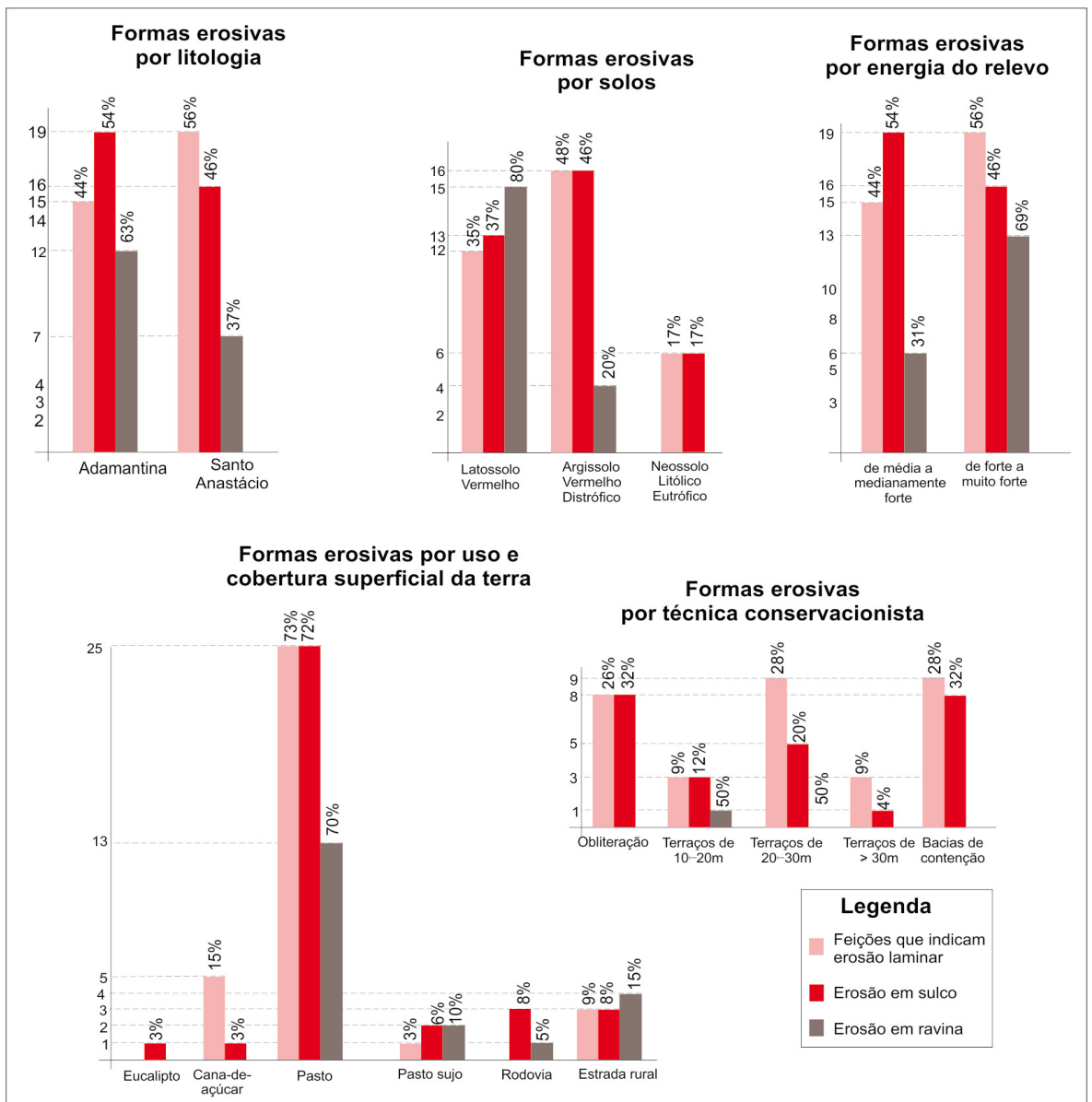

Figura 7 - Formas erosivas por característica física, uso da terra e técnicas conservacionistas em vertentes convexas na alta bacia do ribeirão Areia Dourada, Marabá Paulista (SP) 
A conexão entre os elementos físicos ocorre de maneira equilibrada, de modo que todas as classes temáticas se conectam sem destaque específico, enquanto as distribuições das formas erosivas apresentam distinção na incidência e evolução do processo.

Quanto à geologia, ocorre maior concentração de sulcos e ravinas na Formação Adamantina, uma vez que esta abarca os terrenos do topo à média vertente, de maior amplitude altitudinal, embora na Formação Santo Anastácio também incidam feições em ravinas, muitas das quais se localizam na baixa vertente, mais especificamente nas margens fluviais (Figura 8).
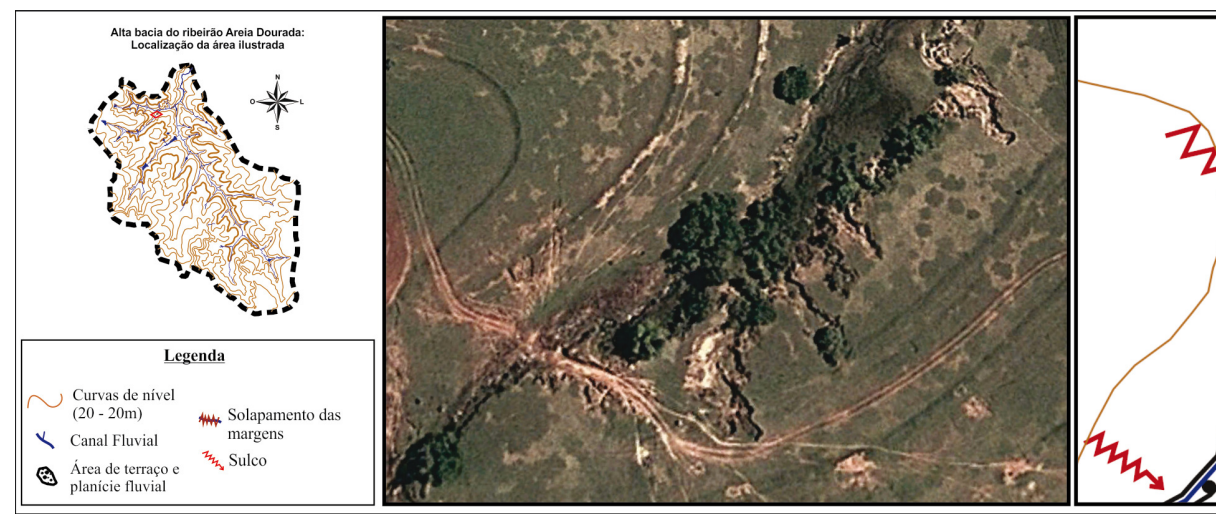

Figura 8 - Ravinas em vertentes convexas com origem no desbarrancamento das margens fluviais

Stein, Ponçano e Saad (2003), avaliando os processos erosivos no ribeirão Areia Dourada, identificaram que o fenômeno destacado na Figura 8 ocorre pelo fato das águas pluviais alcançarem rapidamente os canais fluviais, de modo a produzir enchentes em curto espaço de tempo. Tal situação, aliada ao assoreamento dos canais, induz ao extravasamento e promovem o solapamento das margens, gerando o colapso na baixa vertente, que tende a evoluir a montante, originando ravinas e/ou voçorocas.

Em relação aos solos, no Latossolo e Argissolo incidem feições que indicam erosão laminar, sulco e ravina, enquanto nos Neossolos não se constata evolução do processo para ravinas. Há uma maior concentração de ravinas (Figura 7) nos Latossolos (aproximadamente $80 \%$ ), enquanto nos Argissolos ocorre maior concentração de feições que indicam erosão laminar (48\%) e sulcos (46\%). Essa distinção na concentração e desenvolvimento das formas erosivas entre as duas classes de solos ocorre, potencialmente, devido às características internas dos perfis pedológicos. Ambos apresentam maior quantidade de fração areia, sendo que no Latossolo essa concentração é praticamente idêntica em todo perfil, enquanto no Argissolo há uma maior concentração de argila na camada de subsuperfície, o que, provavelmente, retarda o aprofundamento do processo erosivo, reduzindo o desenvolvimento de formas como a ravina, caracterizada por maior incisão. Em terrenos com Neossolo, incidem seis sulcos e seis setores com marcas que indicam a erosão laminar; nessas áreas não se averigua o desenvolvimento do processo linear, uma vez que o horizonte A chernozêmico caracteriza-se por agregação e grau de desenvolvimento moderado a forte, reduzindo o efeito erosivo nessa classe de solo.

Adistribuição das formas erosivas na energia do relevo também evidencia a predisposição das classes temáticas ao desencadeamento dos processos denudativos, já que há maior concentração de ravinas (69\%) nas classes forte a muito forte, em relação às de média a medianamente forte, que apresentam maior número de sulcos (54\%).

O uso da terra revela a perversão da função teórica das vertentes convexas, que tendem a dispersar o fluxo de água. Nesta classe temática, as feições lineares incidem em maior quantidade nas áreas de pasto, sendo maior ou igual a $70 \%$ em todas as formas erosivas levantadas (Figura 7), boa parte dessas em conexão com energia de forte a muito forte. Este dado, assim como evidenciado nas áreas de topo, indica o superpastoreio dos terrenos, que promove a compactação da camada superficial do solo e a formação de caminhos preferenciais para o escoamento de água através dos percursos percorridos pelo gado, como demonstrado na Figura 8.

Apenas os terrenos recobertos por reflorestamento e vegetação nativa não apresentam forma erosiva associada. Em todas as demais classes de uso da terra, constata-se a presença de feição erosiva, em menor quantidade quando comparada ao pasto. As ravinas se localizam em área de pasto sujo, estradas e rodovias, nestas duas devido à má projeção, que permite a concentração do escoamento das águas pluviais. Nas áreas com cana-de-açúcar, a maior 
correção dos terraços agrícolas possibilita, mesmo nos terrenos com energia forte a muito forte, que o processo se mantenha reduzido e limitado a estágios iniciais do fenômeno erosivo. Na área de eucalipto ocorre uma única feição em sulco, promovida pelo pisoteio do gado que atravessa a área, segundo dados verificados in loco.

Distintas técnicas conservacionistas foram aplicadas. Nas áreas de pasto averígua-se que todas as técnicas existentes neste compartimento do relevo apresentam baixa eficácia, uma vez que se fazem presentes feições em ravinas, sulcos e marcas que indicam erosão laminar em todas elas.

As vertentes côncavas, com maior predisposição a processo denudativos pela tendência de concentração do fluxo, apresenta 57 distintas combinações entre os elementos físicos e antrópicos. As formas erosivas, em diferentes níveis de desenvolvimento, se distribuem por todas as características físicas. Portanto, registra-se que a forma côncava do relevo potencializa a ação morfogenética, onde, com exceção do Neossolo, registram-se voçorocas em todas as demais variáveis do meio físico (Figura $9 \mathrm{e}$ Figura 10).

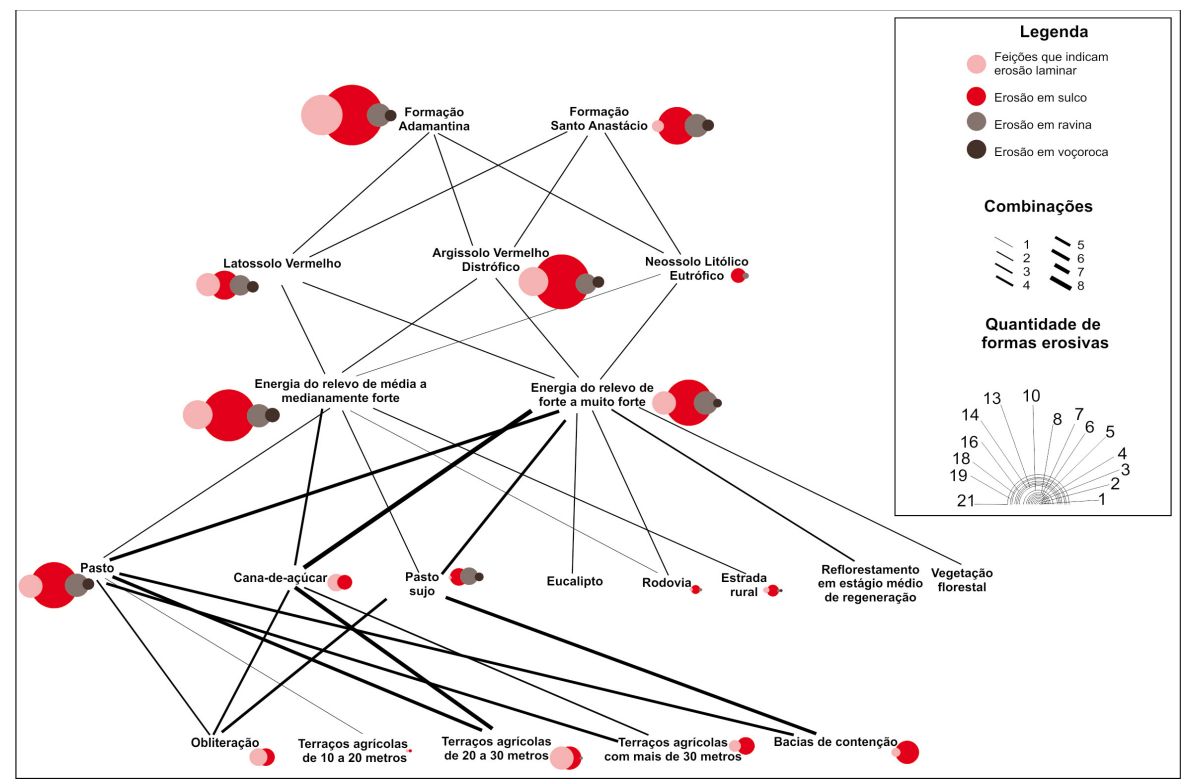

Figura 9 - Interações espaciais em vertentes côncavas na alta bacia do ribeirão Areia Dourada, Marabá Paulista (SP)

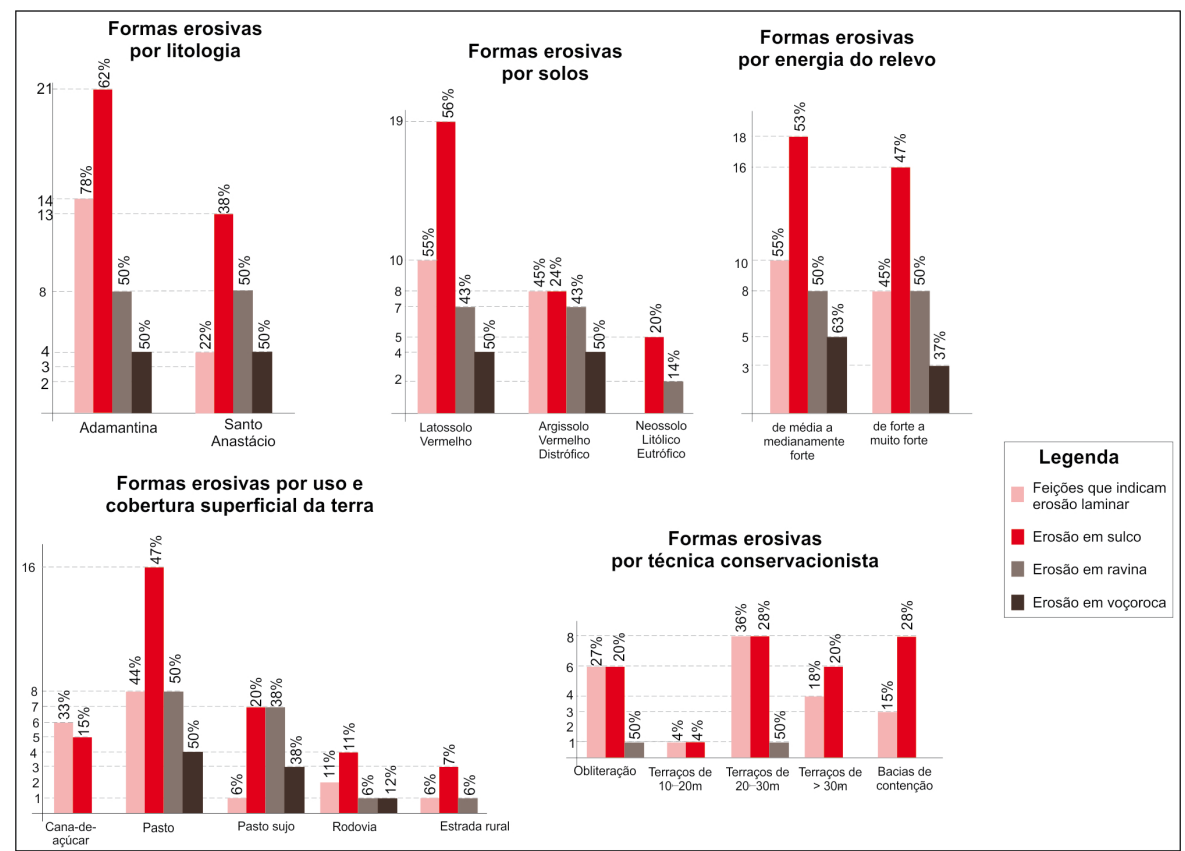

Figura 10 - Formas erosivas por característica física, uso da terra e técnicas conservacionistas em vertentes côncavas na alta bacia do ribeirão Areia Dourada, Marabá Paulista (SP) 
Das Formações geológicas presentes na área, a distribuição das formas erosivas apresenta uma concentração de marcas que indicam erosão laminar e sulcos na Formação Adamantina. Assim, entende-se que nas altitudes mais elevadas da bacia, onde domina a referida formação, há uma maior tendência ao registro de formas erosivas em estágio inicial (sulcos e marcas de erosão laminar). Contudo, há um comportamento idêntico entre as Formações Adamantina e Santo Anastácio quando se tratam de formas mais avançadas, como ravinas e voçorocas (figura 4).

Quanto aos solos, a incidência das feições erosivas, sobretudo ravinas e voçorocas, ocorre em número idêntico tanto nos Argissolos como nos Latossolos - em ambos se verificam sete ravinas e quatro voçorocas. Há discrepância em relação aos sulcos, que apresenta maior incidência no Argissolo, aproximadamente 2,5 vezes a mais que no Latossolo. Este maior volume de sulcos no Argissolo tem a mesma relação apresentada nas convexidades, no entanto, nas concavidades essas feições têm maior tendência à evolução para formas mais avançadas do processo erosivos em ambas as classes de solo. A classe Neossolo Litólico Eutrófico apresenta baixa incidência de processos denudativos, diferentemente dos topos e vertentes convexas, nas concavidades a forma erosiva se desenvolve ao nível de ravinamento.

A energia do relevo também demonstra que as concavidades tendem a generalizar a ocorrência dos processos denudativos, entretanto, nessa variável ocorre perversão das classes temáticas em relação a tais processos, de modo que nos terrenos com potencial de acúmulo de energia média a medianamente forte incidem maior quantidade de marcas que indicam erosão laminar, sulcos e voçorocas, - sendo que as ravinas ocorrem em quantidade idêntica aos terrenos sob energia forte a muito forte. Essa distorção é compreendida ao avaliar a conexão entre a energia do relevo e o uso da terra. Embora as conexões sejam maiores entre as classes de energia forte a muito forte e as diversas classes temáticas de uso da terra, a Figura 9 registra situações em que as classes de energia de média a medianamente forte se conectam com as estradas rurais, e, nestas, incidem marcas que indicam erosão laminar, sulcos e voçoroca, gerando, assim, a discrepância em relação à energia muito forte, uma vez que esta classe temática não se conecta às estradas rurais, as quais são construídas em condições de relevo mais aplainado. .

Com relação às demais classes de uso da terra, constata-se que o pasto e pasto sujo são catalisadores dos processos denudativos, de modo que concentram $88 \%$ das ravinas e voçorocas, $67 \%$ dos sulcos e $50 \%$ da erosão laminar (Figura 10). Quanto ao cultivo de cana-de-açúcar, quando comparado com a concentração de feições denudativas nos topos e convexidades, nota-se que nas concavidades há maior presença de feições que indicam erosão laminar e sulcos, uma vez que mesmo com as correções periódicas dos carreadores, o processo erosivo se faz mais ativo.

Sobre as técnicas conservacionistas, os dados demonstram uma baixa eficiência destas, visto que em todas elas incidem formas que indicam erosão laminar e sulcos. A de maior eficácia compreende os terraços de $10 \mathrm{~m}$ a $20 \mathrm{~m}$, que apresentam um sulco e um setor com marcas que indicam erosão laminar. Nas áreas de obliterações e com bacias de contenção, ocorrem dezenas de feições em sulcos, ravinas e marcas que indicam erosão laminar (Figura 11).

Em determinadas situações, como em bacias com processos erosivos ativos, o uso de práticas conservacionistas, como levantado por Stein, Ponçano e Saad (2003) na bacia do Rio Santo Anastácio, originam recargas inconvenientes dos lençóis, de modo a desenvolver formas erosivas ou ampliar fenômenos existentes.

Ao avaliar o conjunto das informações, constata-se que determinadas variáveis físicas proporcionam maior predisposição a processos erosivos, sendo que, algumas dessas, como as concavidades, têm maior relevância em relação às outras classes temáticas. No entanto, em todas as formas de relevo avaliadas, registrou-se o superpastoreio como catalisador de processos denudativos, e que, de modo geral, as técnicas conservacionistas adotadas pouco contribuem para conter a formação desses fenômenos quando em terrenos de uso intenso, sendo as áreas com vegetação nativa ou reflorestamento mais apropriadas para o pastoreio.

Os dados demonstram algumas contradições quando comparados com aqueles levantados por Stein, Ponçano e Saad (2003) para a bacia do ribeirão Areia Dourada. Os autores destacaram que as áreas de pasto apresentam uma indução de risco atual à erosão de forte a muito forte, no mesmo patamar que a cana-de-açúcar. $\mathrm{Na}$ avaliação por meio dos gráficos em rede, constatou-se que o pasto tem potencial de gerar processos erosivos lineares, que se desenvolvem como ravinas em setores teoricamente pouco sujeitos a tais fenômenos, 
como nas vertentes convexas. Nos terrenos recobertos por cana-de-açúcar, os processos erosivos incidem com menor frequência quando comparados ao pasto, e não evoluem para estágios mais avançados, limitando-se à erosão laminar e aos sulcos. Assim, constata-se menor ocorrência de processos erosivos nas áreas com cultivo de cana-de-açúcar. Quanto aos solos, os referidos autores destacam maior tendência erosiva naqueles de maior diferenciação textural. No entanto, na alta bacia do ribeirão Areia Dourada, no Latossolo Vermelho, principalmente nas vertentes convexas, constatou-se maior frequência de ravinas, enquanto nas vertentes côncavas, a incidência de feições em ravinas e voçorocas é idêntica no Latossolo e Argissolo.

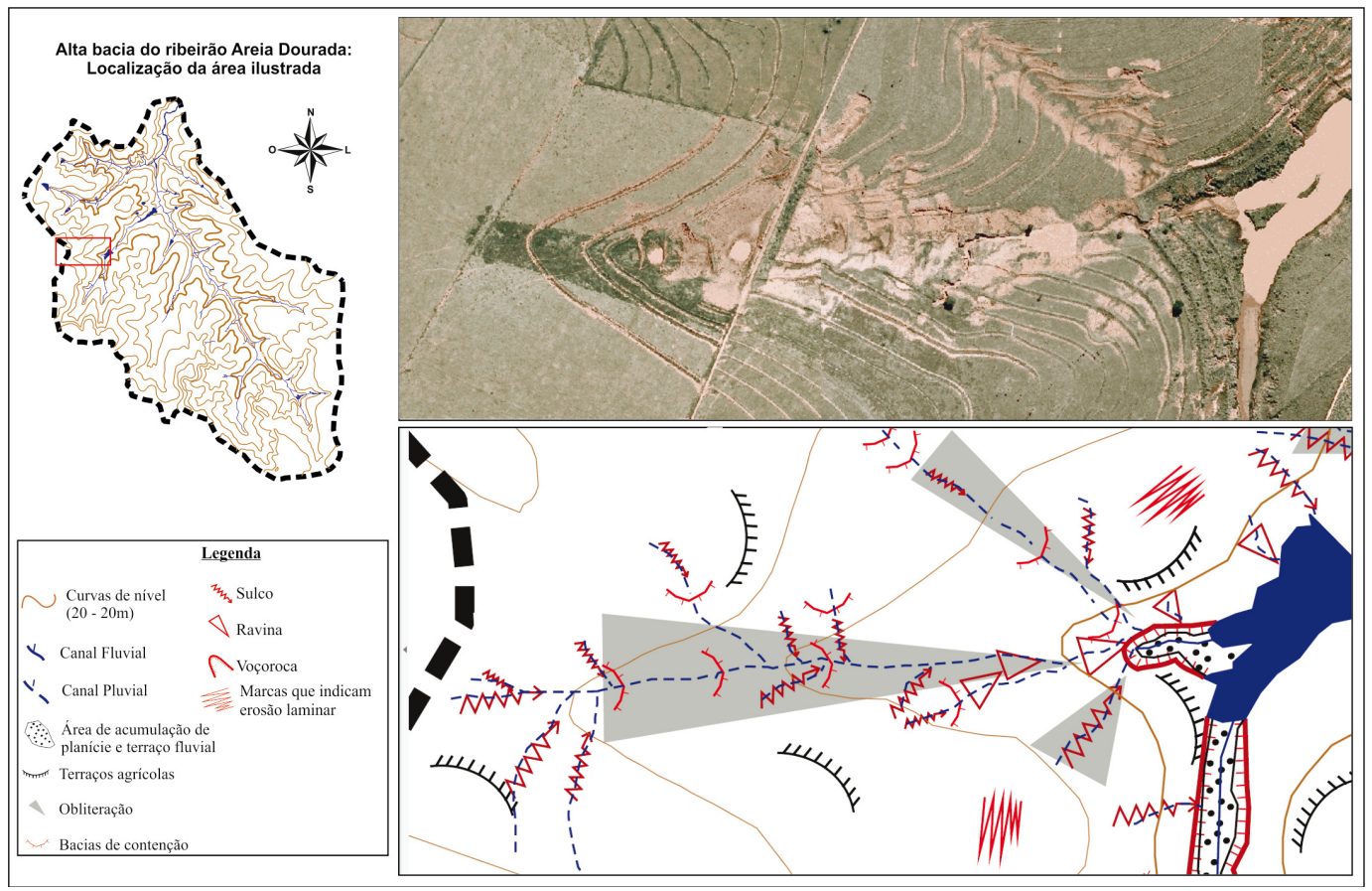

Figura 11 - Presença de sulcos e ravinas em áreas com terraços agrícolas, bacias de contenção e obliteração

\section{Considerações Finais}

$\mathrm{Na}$ análise dos dados, observa-se que a ação humana tem um papel catalisador dos processos erosivos, de forma a generalizar sua ocorrência. Dentre as variáveis, o pasto destaca-se como principal responsável pelo aceleramento dos processos erosivos. Sobre esse uso, averiguou-se a perversão dos sistemas naturais em situações em que o pisoteio excessivo do gado resultou em processos erosivos lineares nas áreas de topo, as quais, pelo baixo declive, não deveriam estar sujeitas ao surgimento de tais processos.

Por outro lado, os gráficos também demonstram que as formas erosivas lineares atingem maior grau de desenvolvimento onde os atributos físicos indicam maior predisposição à atuação morfodinâmica, como a presença de voçorocas apenas nas vertentes côncavas e de ravinas em classes de energia do relevo de média a medianamente forte, e de forte a muito forte nas ver- tentes convexas e côncavas. Nos topos, o fenômeno atinge apenas o nível de sulco. Quanto aos solos, foi constatado que nos Argissolos há maior predisposição para desenvolvimento de sulcos, no entanto, nos Latossolo as feições lineares se desenvolvem em maior profundidade em relação ao Argissolo, atingindo estágios mais avançados do processo, como ravinas e voçorocas. Esse fenômeno se deve a maior porcentagem de areia, sobretudo de areia fina, por todo perfil nessa classe de solo, enquanto no Argissolo, a maior concentração de argila no horizonte subsuperficial retarda a evolução dos sulcos para ravinas.

Das 167 distintas combinações identificadas, averígua-se que em 136 há alguma técnica conservacionista associada, sendo que todas as combinações são acompanhadas de processos erosivos, o que evidencia a baixa eficiência de tais técnicas. Na área estudada, as mesmas técnicas foram utilizadas nas mais diversas combinações, independente da fragilidade dos solos, da 
forma e potencial de acúmulo de energia desse relevo, e das características do uso e cobertura superficial da terra. Esse fato, provavelmente, colabora com a baixa eficiência das técnicas para a contenção dos processos erosivos.

Quanto aos gráficos em rede, ao considerar a dificuldade na representação gráfica de distintas variáveis e suas relações, eles possibilitaram a análise integrada dos elementos, contribuindo para o entendimento da distribuição espacial das formas erosivas e do desenvolvimento dos processos morfogenéticos, de modo a indicar elementos catalisadores de tais processos.

\section{Agradecimentos}

À Fundação de Amparo à Pesquisa do estado de São Paulo (FAPESP), processo número 2012/01553-0.

Ao parecerista pelas importantes contribuições na melhoria deste trabalho.

\section{Referências Bibliográficas}

BASTOS, A. S.; MANIESI, V.; GOMES, F. B. Vulnerabilidade natural à erosão no sudoeste da Amazônia associada aos seus modos de ocupação - o caso do entorno da terra indígena Uru Eu Wau Wau. Revista Brasileira de Geomorfologia. v.16, $\mathrm{n}^{\circ}$ 2, p.271-282, 2015. DOI: http://dx.doi.org/10.20502/rbg.v16i2.386

BOIN, M. N. Chuvas e erosão no Oeste Paulista: uma análise climatológica aplicada. Tese (Doutorado em Geociências e Meio Ambiente), Universidade Estadual Paulista, Rio Claro, 2000. 264p.

BOIN, M. N.; ZANATTA, F.A.S; CUNHA, C.M.L. Avaliação da morfometria do relevo da alta bacia hidrográfica do ribeirão Areia Dourada, Marabá Paulista (SP). Caderno Prudentino de Geografia. Presidente Prudente, v.2, p. 5-26, 2014.

CABECAUER, T.; HOFIERKA, J. The consequences of land cover changes on soil erosion distribuition in Slovakia. Geomorphology (98), p.187-198, 2008. DOI: https://doi. org/10.1016/j.geomorph.2006.12.035

CARVALHO, W. A. (coord.) Levantamento semidetalhado dos solos da bacia do Rio Santo Anastácio-SP. Presidente Prudente, São Paulo: FCT-UNESP, 1997, v.1 e v.2. [s.n.].

CHRISTOFOLETTI, A. Geomorfologia. São Paulo: Edgard Blücher, $2^{\mathrm{a}}$ edição, 1980. 188p.

CUNHA, C. M. L.; MENDES, I. A.; SANCHEZ, M. C. A cartografia das perdas de solo por erosão e a propriedade rural: a busca de uma unidade espacial de mapeamento. Geografia, Rio Claro, vol. 24(2), p.21-35, 1999.

FERNANDES, L.A. Estratigrafia e evolução geológica da parte oriental da Bacia Bauru (Ks, Brasil). 1998. Tese (Doutorado em Geologia Sedimentar) - Instituto de Geociências, Universidade de São Paulo, São Paulo, 1998. 216p.

FERRARI LEITE, J. A ocupação do Pontal do Paranapanema. São Paulo: Editora Hucitec, 1998. 202p.

GARCÍA-RUIZ, J. M.; NADAL-ROMERO, E.; LANARENAULT, N.; BEGUERÍA, S. Erosion in Mediterranean Landscapes: Changes and future challenges. Geomorphology. v.198, p. 20-36,2013. DOI: https://doi.org/10.1016/j. geomorph.2013.05.023

INSTITUTO DE PESQUISAS TECNOLÓGICAS DO ESTADO DE SÃO PAULO (IPT, 1994). Orientações para controle de erosão na bacia do Rio Santo Anastácio - $3^{\mathbf{a}}$ fase, IPT. Relatório, No32.257, 1994, [s.n.].

INSTITUTO DE PESQUISAS TECNOLÓGICAS (IPT, 2012). Cadastramento de pontos de erosão e inundação no estado de São Paulo, Relatório Técnico No 131.057-205, [s.n.].

INSTITUTO DE PESQUISAS TECNOLÓGICAS (IPT), 2015. Cadastro de erosões e inundações. Disponível em: $<\mathrm{http}: / /$ www.ipt.br/noticias_interna.php?id_noticia $=928>$. Acesso em: 09 de fevereiro de 2017.

LESSCHEN, J. P.; CAMMERAAT, L. H.; NIEMAN, T. Erosion and terrace failure due to agricultural land abandonment in a semi-arid environment. Earth Surface Processes and Landforms. v.33, p. 1574-1584, 2008. DOI: 10.1002/esp.1676

MARKER, M.; ANGELI, L.; BOTTAI, L.; COSTANTINI, R.; FERRARI, R.; INNOCENTI, L.; SICILIANO, G. Assessment of land degradation susceptibility by scenario analysis: A case study in Southern Tuscany, Italy. Geomorphology. (93), p. 120-129, 2008. DOI: https://doi.org/10.1016/j.geomorph.2006.12.020

MENDES, I. A. A dinâmica erosiva do escoamento pluvial na bacia do Córrego Lafon - Araçatuba - SP. Tese (Doutorado em geografia). Faculdade de Filosofia Letras e Ciências Humanas, Universidade de São Paulo, São Paulo, 1993. 171p.

MONBEIG, P. Pioneiros e fazendeiros de São Paulo. São Paulo: Editora Hucitec, 1984. 392p.

PEREZ-FILHO, A.; QUARESMA, C. C. Ação antrópica sobre as escalas temporais dos fenômenos geomorfológicos. Revista Brasileira de Geomorfologia. v.12, n ${ }^{\circ} 3$, p. 83-90, 2011. DOI: http://dx.doi.org/10.20502/rbg.v12i0.261 
SHREVE, E. L. Infinite topologically random channel networks. The Journal of Geology. v.75, №2, p.178-186, 1967.

STEIN, D. P. Avaliação da degradação do meio físico. Bacia do Rio Santo Anastácio. Oeste Paulista. Tese (Doutorado em Geociências e Meio Ambiente). Instituto de Geociências e Ciências Exatas, Universidade Estadual Paulista, Rio Claro, 1999. [s.n.].
STEIN, D. P.; PONÇANO, W. L.; SAAD, A. R. Erosão na bacia do Rio Santo Anastácio, Oeste do estado de São Paulo, Brasil. Revista Geociências. v.22, n.2, p.143-161, 2003.

ZANATTA, F. A. S. Diagnóstico visando planejamento ambiental da alta bacia do ribeirão Areia Dourada, Marabá Paulista (SP). Dissertação (Mestrado em Geografia - Organização do Espaço). Universidade Estadual Paulista, Rio Claro, 2013. 140f. 